\title{
ANALYSIS OF CHEMISTRY TEACHERS' COVALENT BOND CONCEPTUAL UNDERSTANDING THROUGH DIAGNOSTIC INTERVIEW TECHNIQUE
}

\author{
Mashfufatul Ilmah", Yahmin Yahmin ${ }^{2}$, Muntholib Muntholib ${ }^{2 *}$ \\ ${ }^{1}$ Chemistry Education, Postgraduate Program, Universitas Negeri Malang - Indonesia \\ ${ }^{2}$ Chemistry Department, Universitas Negeri Malang - Indonesia
}

\begin{abstract}
Abstrak - Pemahaman konseptual yang dimiliki guru merupakan bagian penting dalam proses pembelajaran. Konsep ikatan kovalen adalah dasar untuk mempelajari konsep lain dalam kimia. Namun demikian, hasil penelitiain menunjukkan bahwa guru masih memiliki miskonsepsi tentang ikatan kovalen. Tujuan penelitian ini adalah mempelajari pemahaman konsep ikatan kovalen pada guru kimia menggunakan wawancara diagnostik. Jenis wawancara yang digunakan adalah wawancara semiterstruktur. Subjek penelitian adalah delapan guru kimia dari sekolah yang berbeda. Penelitian ini menerapkan desain penelitian deskriptif-kualitataif. Analisis data dilakukan dengan menggunakan kerangka fenomenografi. Hasil penelitian menunjukkan bahwa pemahaman guru pada konsep ikatan kovalen terdiri dari 25\% paham konsep, 22,75\% tidak paham konsep, dan 52,25\% miskonsepsi. Miskonsepsi dapat ditemukan pada konsep tujuan atom berikatan, ikatan kovalen koordinasi, jenis atom yang membentuk ikatan kovalen, ikatan kovalen polar dan nonpolar, urutan kepolaran ikatan kovalen, penulisan struktur Lewis, dan panjang ikatan kovalen.
\end{abstract}

Kata kunci: Pemahaman konseptual, Guru kimia, miskonsepsi, ikatan kovalen, wawancara diagnostik

\begin{abstract}
Conceptual understanding of the subject matter is crucial for teachers in conducting instruction. The covalent bond is one of the essential knowledge of chemistry. This knowledge underlies most of the chemistry body knowledge. The purpose of this study is to investigate the chemistry teachers' conceptual understanding of covalent bonds. This study applied a descriptive qualitative research design. The research subjects were eight chemistry teachers from different schools. Data collection was carried out using a diagnostic interview technique guided by the semistructured interview protocol. Data analysis was performed using phenomenography techniques. The results show that $25.00 \%$ of the interviewees well understood the covalent bond concepts, $22.75 \%$ do not understand, and $52.25 \%$ have misconceptions. Chemistry teachers have misconceptions about the concepts of intents of atom forming bonds, coordination bonds, types of atoms that form covalent bonds, polar and nonpolar covalent bonds, the level of covalent bonds polarity, Lewis structure writing, and covalent bond length.
\end{abstract}

Keywords: Conceptual understanding, Chemistry teacher, Misconception, Covalent bond, Diagnostic interview

\section{INTRODUCTION}

Conceptual understanding is one of the teachers' primary professional competence since it affects students' learning progress (Kleickmann et al., 2013). Their conceptual comprehension has been proven to impact the way teachers carry out their teaching (Baumert et al., 2010; Hill et al., 2005). Therefore, to create an effective learning process, teachers have to possess excellent conceptual understanding (Mavhunga \& Rollnick, 2016). Besides, they also have to have a broader knowledge than the ones learned by the students (Bergqvist \& Rundgren, 2017). The comprehension

\footnotetext{
*Corresponding author: muntholib.fmipa@um.ac.id
} 
limitation and misconception cause students to experience learning difficulties and misconceptions (Kolomuç \& Tekin, 2011).

Studies suggest that the covalent bond concept is presumed to be complicated by students and teachers (Bergqvist et al., 2016; Dhindsa \& Treagust, 2014; Nahum et al., 2010). Ir is the fundamental concept in chemistry. The concepts within the covalent bond theory are the students' fundamental to understand ionic bonds (Dhindsa \& Treagust, 2014). Additionally, the covalent bond is also related to the other chemical concepts, such as molecular structure, compound physical and chemical features, as well as chemical reaction (Özmen, 2004). However, the misconception on the covalent bond is frequently observed, such as the types of the atom with a covalent bond, the process of covalent bond formation, and types of covalent bonds (Ünal et al., 2010), the writing of Lewis structure (Ardiansah et al., 2014; Cooper et al., 2010), electronegativity (Eymur \& Geban, 2017), octet rule (Luxford \& Bretz, 2014; Ultay, 2015; Vrabec \& Prokša, 2016), and the covalent bond length (Erman, 2016). The misconception of the covalent bond is found in senior high school students and college students (Burrows \& Mooring, 2015; Luxford \& Bretz, 2013). The misconception is even discovered in teachers of secondary schools (Ardiansah et al., 2014; Kolomuç \& Tekin, 2011).

The research conducted by Ardiansah et al. (2014) on the high school chemistry teachers' understanding of chemical concept bonding reveals that only $21 \%$ of teachers know the concepts, while $57 \%$ have a misconception, and $22 \%$ of teachers do not know the concept. It indicates that teachers' understanding of chemical bonds is categorized as low. In other words, the teachers have not fulfilled the professional teacher standard competencies, which cover teacher wide and deep lesson mastery, with no misconception. Therefore, an analysis of teacher conceptual understanding is required as an initial step to improve the covalent bond learning quality.

Teachers' conceptual understanding of a concept can be measured using diagnostic interviews (Montfort et al., 2007). Among other misconception diagnostic methods, an interview has an essential role since it investigates deeper and aids in obtaining a more detailed description of the teacher's cognitive structure (Gurel et al., 2015). Even with guidelines, teachers' answers carry flexibility to researchers to ask more profound questions than the designated questions to attain a broader answer to the teacher's conceptual mastery (Adhabi \& Anozie, 2017). Some studies have proven that the diagnostic interview reveals students' conceptual understanding (Linenberger \& Bretz, 2012; Montfort et al., 2007; Ünal et al., 2010). Thus, this research aims to analyze the covalent bond conceptual understanding of chemistry teachers using diagnostic interviews.

\section{METHOD}

This research used a descriptive design with a qualitative approach. Descriptive research aims to describe teachers' understanding of the covalent bond concept. The qualitative approach was selected to attain a more profound meaning from the research findings, a complete overview of the research finding, and a detailed research process description. The subjects were eight chemistry teachers in Banten from different schools. The researchers acted as the primary instruments in the qualitative research while the interview guideline was used to guide the researchers to stay in the investigated topic. The selected interview type was a semi-structured interview, with interview guidelines had been validated by the chemistry lecturer in Universitas Negeri Malang. The obtained interview data were transcribed and went to a validity check through the member check technique. The data analysis was carried out referring to phenomenographic analysis framework (Ebenezer, 1996) consisting of transcribing the interview recording, coding the data to ease the searching process, reducing the data that is not related to the research focus, classifying data to categorize teachers' understanding based on the answer criteria of Abraham at al. (1992), presenting the data and creating the conclusion. 
Table 1. Criteria of Interview Answer Pattern

\begin{tabular}{|c|c|c|}
\hline Answer Criteria & Level of Understanding & Category \\
\hline The answer is correct and covers all aspects & $\begin{array}{l}\text { Completely understand the } \\
\text { concept }\end{array}$ & $\begin{array}{l}\text { Understand } \\
\text { the concept }\end{array}$ \\
\hline $\begin{array}{l}\text { The answer indicates, at least, one correct aspect, with no } \\
\text { misconception, even if not all aspects are answered }\end{array}$ & Partially understand & \\
\hline $\begin{array}{l}\text { The answer shows some concept mastery, but some other } \\
\text { parts indicate misconception }\end{array}$ & $\begin{array}{l}\text { Partially understand with a } \\
\text { misconception }\end{array}$ & Misconception \\
\hline Wrong answer & Misconception & \\
\hline $\begin{array}{l}\text { Repeat the question, with no relevant and clear answer } \\
\text { I don't know, I don't understand, or give no answer }\end{array}$ & $\begin{array}{l}\text { Do not understand } \\
\text { No answer }\end{array}$ & $\begin{array}{l}\text { Do not } \\
\text { understand }\end{array}$ \\
\hline
\end{tabular}

\section{RESULTS AND DISCUSSION}

The classified teachers' understanding of covalent bonds is presented in Table 2.

Table 2. Chemistry Teachers' Understanding of Covalent Bond

\begin{tabular}{|c|c|c|c|c|c|c|}
\hline \multirow[t]{2}{*}{ Sub-concept } & \multicolumn{2}{|c|}{ Understand } & \multicolumn{2}{|c|}{ Misconception } & \multicolumn{2}{|c|}{$\begin{array}{l}\text { Not } \\
\text { Understand }\end{array}$} \\
\hline & $\Sigma$ & $\%$ & $\Sigma$ & $\%$ & $\Sigma$ & $\%$ \\
\hline Purposes of bonded atoms & - & - & 8 & $100 \%$ & - & - \\
\hline Covalent bond and coordinate bond & 6 & $75 \%$ & 2 & $25 \%$ & - & - \\
\hline Types of atoms that form covalent bond & 1 & $12.5 \%$ & 7 & $87.5 \%$ & - & - \\
\hline Polar and nonpolar covalent bonds & 4 & $50 \%$ & 4 & $50 \%$ & - & - \\
\hline The order of polarity of covalent bonds & 4 & $50 \%$ & 4 & $50 \%$ & - & - \\
\hline Molecule's formal charge and stability & 3 & $37.5 \%$ & - & - & 5 & $62.5 \%$ \\
\hline Lewis structure writing & - & - & 8 & $100 \%$ & - & - \\
\hline Octet rule & - & - & 8 & $100 \%$ & - & - \\
\hline Covalent bond length on ethane, ethene, ethane & 3 & $37.5 \%$ & 2 & $25 \%$ & 3 & $37.5 \%$ \\
\hline Covalent bond length on hydrogen halide & 1 & $12.5 \%$ & 3 & $37.5 \%$ & 4 & $50 \%$ \\
\hline Average & 2 & $25 \%$ & 4.18 & $52.25 \%$ & 1.82 & $22.75 \%$ \\
\hline
\end{tabular}

Table 2 shows that the average percentage of teachers who understand the concept is $25 \%$. The highest understand percentage of $75 \%$ is observed in the covalent and coordinate bond concept. The teachers' comprehended covalent bond concept is the bond formed by the sharing electron bond, while the coordinate bond occurs if the pair electron used in the bond only comes from one atom. All teachers correctly understand the covalent and coordinate bond concept. An example of a teachers' covalent bond is the bond between atom $\mathrm{H}$ and $\mathrm{Vl}$ on the $\mathrm{HCl}$ molecule. All teachers can correctly provide the covalent bond. Meanwhile, teachers' coordinate bond example is the bond among $\mathrm{N}$ and $\mathrm{B}$ atoms on $\mathrm{NH}_{3}-\mathrm{BF}_{3}$ molecule and the bond between $\mathrm{O}$ and $\mathrm{S}$ atom on $\mathrm{H}_{2} \mathrm{SO}_{4}$ molecule. Both examples are illustrated in Figures 1 and 2. 


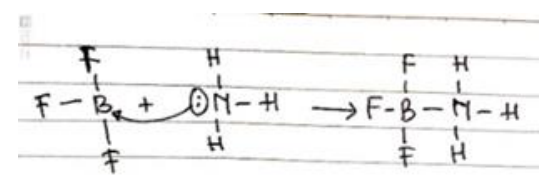

Figure 1. The bond on $\mathrm{NH}_{3} \mathrm{BF}_{3}$ molecule

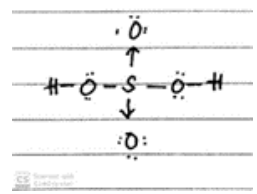

Figure 2. The bond on the $\mathrm{H}_{2} \mathrm{SO}_{4}$ molecule

Figure 1 shows that the teachers with conceptual understanding offer the correct covalent bond example, while Figure 2 shows the teachers who understand the concept but fail to give the proper example. The teacher's mistakes in giving coordinate bond examples occur due to their inability to write the correct Lewis structure of $\mathrm{H}_{2} \mathrm{SO}_{4}$. The teachers' H2SO4 Lewis structure is not following the experimental fact and the formal charge of the atoms is not equal to zero. The interview results reveal that this misconception emerges since teachers follow the coordinate bond example provided in the textbook without reviewing the example. After the textbook was checked, the bond between atom $\mathrm{O}$ and $\mathrm{S}$ in the $\mathrm{H}_{2} \mathrm{SO}_{4}$ molecule is the coordinate covalent. Similar results are also discovered in a study conducted by Erman (2016), that one of the misconception sources is the textbook. Therefore, the teachers have to be more thorough in selecting the textbook. They have also to ensure that the learning source has no misconception.

In addition, the data presented in Table 2 also shows that the average percentage of teachers with no conceptual understanding is $22.75 \%$. This category is highly observed in the bond order concept $(100 \%)$. The teachers said they forgot or had no idea about the bond order and the number of bond order among atoms on ethane, ethene, ethane molecule. All teachers do not understand that bond order is the number of covalent bonds that occur between two atoms. The amount of covalent bond among the $\mathrm{C}$ atoms on the ethane, ethene, and ethane are one, two, and three, respectively. Thus their bond order number are also one, two, and three, respectively. The bond order concept has to be comprehended by the teachers since this concept is closely related to the covalent bond length.

The molecule's formal charge concept and stability also present a high not understanding criteria percentage of $62.5 \%$. The teachers in this category unable to explain and estimate the formal charge and explain the relationships among formal charge and stability of molecule or simple polyatomic ion. These teachers presume that this concept is not essential to be taught to the students, as indicated in the interview answer on the formal charge concept below:

Researcher: "in the Lewis structure, those atoms have a formal charge. Do you remember what is the formal charge?"

Teacher : "I forgot, since it is not taught in school, so I forget the definition of formal charge,"

Researcher: "Why is it not taught?"

Teacher: "The book does not mention it, so it is not taught."

That part of the interview answer indicates that the teacher considers the formal charge concept as not a significant concept in the learning process and is not discussed in the textbook. Thus, the teachers do not remember and look for that concept. Teachers should have understood the concept of formal charge since it is used to determine the molecules or polyatomic ion stability in the covalent bond learning. Therefore, as the information source, teachers should have a broader and deeper knowledge since one of the causes of misconception is the teacher's limited information (Erman, 2016).

Table 2 also shows that the misconception category attains the highest percentage of $52.25 \%$. The observed misconceptions are presented in Table 3. 
Table 3. Types of Covalent Bond Misconception Observed on the Chemistry Teachers

\begin{tabular}{|c|c|}
\hline Sub-concept & Misconception \\
\hline \multirow{2}{*}{$\begin{array}{l}\text { Purposes of } \\
\text { bonded atoms }\end{array}$} & Atoms bond to be stable, following the octet or duplet rules. \\
\hline & Atoms bond to be stable, with all pair electron. \\
\hline $\begin{array}{l}\text { Covalent bond } \\
\text { and coordinate } \\
\text { bond }\end{array}$ & $\begin{array}{l}\text { The covalent bond is the bond that occurs from the sharing pair electron. An } \\
\text { example of this bond is among } \mathrm{H} \text { and } \mathrm{Cl} \text { on } \mathrm{HCl} \text {. Meanwhile, the coordinate } \\
\text { bond occurs if the used pair electron comes from one atom, such as the bond } \\
\text { among } \mathrm{O} \text { and } \mathrm{S} \text { atoms on the } \mathrm{H} 2 \mathrm{SO} 4 \text { molecule. }\end{array}$ \\
\hline
\end{tabular}

Types of atoms Only the nonmetal atoms that can form a covalent bond, so that the bond type that form a on $\mathrm{BeCl} 2$ molecule is ion bond since it consists of metal and nonmetal atom. covalent bond

\section{Polar and} nonpolar covalent bonds

The polar covalent bond is the covalent bond with PEB in its centers, such as $\sum \operatorname{Total} \%$

$7 \quad 100 \%$

1

$225 \%$

$\mathrm{H} 2 \mathrm{O}$ and NH3. The nonpolar covalent bond is the covalent bond with no PEB in its center, such as $\mathrm{CH} 4$ and F2.

The atoms on the polar covalent bond have great electronegativity difference, such as $\mathrm{HCl}$. The atoms on a nonpolar covalent bond have a small or zero electronegativity difference, such as $\mathrm{H} 2$.

The polar covalent bond is marked by different atoms, such as $\mathrm{HCl}$. The nonpolar covalent bond is marked by the same atom, such as $\mathrm{H} 2$.

The order of polarity of covalent bonds

The polarity of bond $\mathrm{HF}>\mathrm{HCl}>\mathrm{HBr}$ since the atom size $\mathrm{F}<\mathrm{Cl}<\mathrm{Br}$.

The polarity of bond $\mathrm{HF}>\mathrm{HCl}>\mathrm{HBr}$ since $\mathrm{F}$ can form a hydrogen bond and ordered based on the atom size, and a smaller atom size indicates more polarity.

$\mathrm{HF}, \mathrm{HCl}$, and $\mathrm{HBr}$ has the same polarity bond

Lewis Structure

The Lewis Structure of NO2 is:

The Lewis Structure of NO2 is:<smiles>O=N[O+]=O</smiles><smiles>[Ge]N=[Ge]</smiles>

Atoms that follow the octet rule

The always octet center atom is the atom type IV and V

The always octet center atom is the atom type halogen, and atom $\mathrm{C}$

The always octet center atom is the nonmetal atom

The always octet center atom is the atom $\mathrm{C}, \mathrm{N}, \mathrm{O}, \mathrm{F}, \mathrm{Cl}, \mathrm{Br}, \mathrm{I}$

The always octet center atom is the atom type IVA and VIA

Atoms that can be less than or maximal of octet

Atoms that can be more than octet

Bond length on ethane, ethene, ethane

Bond length on $\mathrm{HF}, \mathrm{HCl}$, and $\mathrm{HBr}$

The center atom with valence shell that can be less than octet is $\mathrm{H}$ and atom type II

The center atom with valence shell that can be less than octet is atom Be

The center atom with valence shell that can be less than octet is $\mathrm{Be}$ and $\mathrm{B}$

The center atom with a valence shell that can be less than octet is atom $\mathrm{S}$

The center atom with valence shell that can be more than octet is atom type VI

The center atom with valence shell that can be more than octet is period three atom

The center atom with valence shell that can be more than octet is atom $\mathrm{P}$ and $\mathrm{S}$

The center atom with a valence shell that can be more than an octet is atom $\mathrm{S}$

The bond length among atom $\mathrm{C}$ on ethane $=$ ethane $=$ ethane

The bond length $\mathrm{HF}>\mathrm{HCl}>\mathrm{HBr}$ since the electronegativity $\mathrm{F}>\mathrm{Cl}>\mathrm{Br}$

The bond length $\mathrm{HF}=\mathrm{HCl}=\mathrm{HBr}$
$250 \%$ 
Table 3 shows that the highest misconception percentage is identified in the Purposes of bonded atoms, Lewis structure writing, and octet rules that reach 100\%. The recognized teachers' understanding of the Lewis structure writing is that they can correctly write the Lewis structure of the simple molecule, such as $\mathrm{HF}, \mathrm{HCl}, \mathrm{H}_{2}$, and $\mathrm{HC}_{4}$ molecules. However, they find difficulties in writing the Lewis structure of the $\mathrm{NO}_{2}$ molecule. The interview results reveal that the teachers' stages in writing Lewis structure include (1) determining the electron configuration of each atom; (2) deciding the center atom; (3) illustrating the Lewis symbol of each atom; (4) pairing each electron from each atom, to form octet or duplet. Those steps generate difficulties for teachers to write the non-octet Lewis structure. All teachers cannot correctly write the Lewis structure of the $\mathrm{NO}_{2}$ molecule, as illustrated in Figures 3 and 4.

\section{$\ddot{o}=\dot{N}=\ddot{o}$}

Figure 3. The bond of $\mathrm{NO}_{2}$ molecule

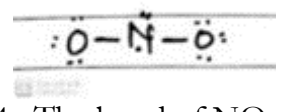

Figure 4. The bond of $\mathrm{NO}_{2}$ molecule

Figure 3 is the Lewis structure drawn by the teacher who understood the formal charge concept. The teacher draws the Lewis structure of the NO2 molecule by making the formal charge of allatom zero. The mistakes in Figure 3 happen since the valence shell of the $\mathrm{N}$ atom has nine electrons. The teachers do not understand that the maximum 2 periods atoms in the valence shell in the octet rule are only eight. $\mathrm{N}$ atom is one of the 2 periods atoms, so that it can not have more than eight electrons. Figure 4 is the Lewis structure made by teachers with no understanding of the formal electron charge that emphasizes the fulfillment of the octet rule on both $\mathrm{O}$ atoms without considering the formal charge. These teachers' mistakes are that the formal charge of both $\mathrm{O}$ atoms is not equal to zero, while the stable Lewis structure should have minimal or close to zero formal charges.

The mistake in the Lewis structure writing caused by the octet rules fulfillment focus has also been identified in a study carried out by Ardiansah et al. (2014); Cooper et al. (2010); Nurbaity \& Mustikasari (2012). Consequently, other than the octet rule, the formal charge concept should also be used to write the Lewis structure. The comfortable and correct Lewis structure writing is presented by the steps arranged by Effendy (2017). The stages consist of (1) determining the center atom, (2) estimating the $\mathrm{BK}$ of the center atom, PEI, and PEB, (3) write the Lewis structure framework, (4) concretizing all substituents, (5) calculating the formal charge of each atom, and (6) transforming the formal charge of the atom equals to zero, and if possible, by changing the PEB into the $\pi$ bond.

\section{CONCLUSIONS}

The teachers' conceptual understanding of covalent bond has not been satisfying $(25 \%$ understand the concept, $22.75 \%$ do not understand the idea, and $52.25 \%$ experience misconception). The misconception is observed on the purpose of bond atoms, covalent and coordinate bond, types of atoms that form a covalent bond, polar and nonpolar covalent bond, the polarity order of covalent bond, and the length of a covalent bond.

The findings from this research confirm the teachers' low covalent bond understanding. That finding should be followed up by (1) identification of ways to accelerate teachers' conceptual understanding of covalent bond, (2) efforts to improve the teaching quality, including the improvement on teachers' conceptual understanding, and (3) analysis of chemistry teachers' conceptual understanding on other chemistry constructs. 


\section{REFERENCES}

Abraham, M. R., Grzybowski, E. B., Renner, J. W., \& Marek, E. A. (1992). Understandings and Misunderstandings of Eighth Graders of Five Chemistry Concepts Found in Textbooks. Journal of Research in Science Teaching, 29(2), 105-120.

Adhabi, E., \& Anozie, C. B. (2017). Literature Review for the Type of Interview in Qualitative Research. International Journal of Education, 9(3), 86-97.

Ardiansah, Enawaty, E., \& Lestari, I. (2014). Miskonsepsi Guru SMA Negeri pada Materi Ikatan Kimia Menggunakan Certainty of Response Index (CRI). Jurnal Pendidikan dan Pembelajaran Khatulistiwa, 3(9), $1-18$.

Baumert, J., Kunter, M., Blum, W., Brunner, M., Voss, T., Jordan, A., ... Tsai, Y.-M. (2010). Teachers' Mathematical Knowledge, Cognitive Activation in the Classroom, and Student Progress. American Educational Research Journal, 47(1), 133-180.

Bergqvist, A., \& Chang Rundgren, S. N. (2017). The influence of textbooks on teachers' knowledge of chemical bonding representations relative to students' difficulties understanding. Research in Science and Technological Education, 35(2), 215-237.

Bergqvist, A., Drechsler, M., \& Chang Rundgren, S. N. (2016). Upper Secondary Teachers' Knowledge for Teaching Chemical Bonding Models. International Journal of Science Education, 38(2), 298-318.

Burrows, N. L., \& Mooring, S. R. (2015). Using concept mapping to uncover students' knowledge structures of chemical bonding concepts. Chemistry Education Research and Practice, 16(1), 53-66.

Cooper, M. M., Grove, N., \& Underwood, S. M. (2010). Lost in Lewis Structures: An Investigation of Student Difficulties in Developing Representational Competence. Journal of Chemical Education, 87(8), 869-874.

Dhindsa, H. S., \& Treagust, D. F. (2014). Prospective pedagogy for teaching chemical bonding for smart and sustainable learning. Chemistry Education Research and Practice, 15(4), 435-446.

Ebenezer, J. V. (1996). Chemistrv Students' Conceptions of Solubility : A Phenomenography. Journal of Science Education, 80(2), 181-201.

Effendy. (2017). Molekul, Struktur, dan Sifat-Sifatnya. Malang: Indonesia Academic Publishing.

Erman, E. (2016). Factors contributing to students' misconceptions in learning covalent bonds. Journal of Research in Science Teaching, 54(4), 520-537.

Eymur, G., \& Geban, Ö. (2017). The Collaboration of Cooperative Learning and Conceptual Change: Enhancing the Students' Understanding of Chemical Bonding Concepts. International Journal of Science and Mathematics Education, 15(5), 853-871.

Gurel, derya K., Eryllmaz, A., East, M., \& Mcdermott, L. C. (2015). A Review and Comparison of Diagnostic Instruments to Identify Students' Misconceptions in Science. Eurasia Journal of Mathematics, Science and Technology Education, 11(5), 989-1008.

Hill, H. C., Rowan, B., \& Ball, D. L. (2005). Effects of teachers' mathematical knowledge for teaching on student achievement. American Educational Research Journal, 42(2), 371-406.

Kleickmann, T., Richter, D., Kunter, M., Elsner, J., Besser, M., Krauss, S., \& Baumert, J. (2013). Teachers' Content Knowledge and Pedagogical Content Knowledge: The Role of Structural Differences in Teacher Education. Joumal of Teacher Education, 64(1), 90-106.

Kolomuç, A., \& Tekin, S. (2011). Chemistry Teachers' Misconception Concerning Concept of Chemicl Reaction Rate. Eurasian Journal of Phisycs and Chemistry Euction, 3(2), 84-101.

Linenberger, K. J., \& Bretz, S. L. (2012). Generating cognitive dissonance in student interviews through multiple representations. Chemistry Education Research and Practice, 13(3), 172-178.

Luxford, C. J., \& Bretz, S. L. (2013). Moving beyond definitions: What student-generated models reveal about their understanding of covalent bonding and ionic bonding. Chemistry Education Research and Practice, 14(2), 214-222.

Luxford, C. J., \& Bretz, S. L. (2014). Development of the bonding representations inventory to identify student misconceptions about covalent and ionic bonding representations. Journal of Chemical Education, 91(3), 312-320.

Mavhunga, E., \& Rollnick, M. (2016). Teacher- or Learner-Centred? Science Teacher Beliefs Related to Topic Specific Pedagogical Content Knowledge: A South African Case Study. Research in Science Education, 46(6), 831-855.

Montfort, D., Brown, S., \& Findley, K. (2007). Using Interviews to Identify Student Misconceptions in Dynamics. 37th Asse/IEEE Frontiers in Education Converence, (October 10-13), 22-27. 
Nahum, T. L., Mamlok-Naaman, R., Hofstein, A., \& Taber, K. S. (2010). Teaching and learning the concept of chemical bonding. Studies in Science Education, 46(2), 179-207.

Nurbaity, \& Mustikasari, I. (2012). Analisis penguasaan konsep ikatan kimia pada mata kuliah kimia organik melalui instrumen two tier. Jurnal Riset Pendidikan Kimia, 2(1), 99-106.

Özmen, H. (2004). Some Student Misconceptions in Chemistry: A Literature Review of Chemical Bonding. Journal of Science Education and Technology, 13(2), 147-159.

Ultay, N. (2015). the Effect of Concept Context-Based Chemistry : Journal of Baltic Science Education, 14(1), 96-108.

Ünal, S., Coştu, B., \& Ayas, A. (2010). Secondary school students' misconceptions of covalent bonding. Journal of Turkish Science Education, 7(2), 3-29.

Vrabec, M., \& Prokša, M. (2016). Identifying Misconceptions Related to Chemical Bonding Concepts in the Slovak School System Using the Bonding Representations Inventory as a Diagnostic Tool. Journal of Chemical Education, 93(8), 1364-1370. 